\title{
Econometric Analysis of Determinants of Livelihood Outcomes of Coffee Producers in Lalo Assabi District, Ethiopia: Education and Income in Focus
}

\author{
Etiyopya Lalo Assabi Bölgesinde Kahve Üreticilerinin Geçim Kaynă̆ Belirleyicilerinin Ĕ̆itim ve \\ Gelir Odaklı Ekonometrik Analizi
}

\author{
Mekonin Abera Negeri \\ Madda Walabu University, Ethiopia (tgmoke@gmail.com)
}

Keywords:
Annual Total
Income
Education
Lalo Assabi
Livelihood
Outcomes
Multiple Linear
Regression

\section{Anahtar}

kelimeler:

Yillik Toplam

Gelir

Ĕ̌itim

Lalo Assabi

Geçim Kaynaklart

Çoklu Lineer

Regresvon

\begin{abstract}
This study aims at identifying major determinants of livelihood outcomes with particular emphasis on the schooling of children proxy to wellbeing, and annual total income of coffee producers in Lalo Assabi district, Ethiopia. Random sample of 141 coffee producers were selected by systematic sampling for interview based on the required sample size. Both descriptive and inferential statistical methods were employed for data analysis. The result of the study explored that the literacy rate in the study area is 78.40 expressed as a percentage. Around $70 \%$ of the annual total income of the sampled households is generated from coffee marketing and/or production. The result of multiple linear regressions revealed that sex, age and year of education of household head as well as square root of annual total income and distance to preparatory school had significant relationship with schooling of children. Similarly, age of household head, tropical livestock holding, access to improved coffee seed, access to credit and total land owned by household had significant relationship with log of annual total income of coffee producers. Thus, these variables need special attention if the wellbeing and annual total income of coffee producers are to be increased.
\end{abstract}

\section{ÖZET}

Bu çalışma, Etiyopya'nın Lalo Assabi ilçesinde kahve üreticilerinin yıllık toplam gelirlerini ve refahın eğitim vekilliği üzerinde özellikle durarak geçim kaynaklarının önemli belirleyicilerini belirlemeyi amaçlamaktadır. Bu kapsamda, 141 kahve üreticisi uygun örnek büyüklügü tayinine dayalı olarak görüşme için sistematik örnekleme yöntemiyle seçilmiştir. Veri analizinde hem tanımlayıcı hem de çıkarımsal istatistiksel yöntem kullanılmıştır. Elde edilen sonuçlara göre, çalışma alanındaki çiftçilerin okuma yazma oranı yüzde 78,40 'dır. Örneklemdeki hanelerin yıllık toplam gelirinin yaklaşık\% 70'i kahve pazarlaması ve / veya üretime dayanmaktadır. Çoklu doğrusal regresyonların sonucu, hane halkı başındaki cinsiyet, yaş ve eğitim yılı ile yıllık toplam gelirin karekökü ve hazırlık okuluna olan uzaklı̆̆ın çocukların okullulaşmasını önemli derecede etkilediğini ortaya koymuştur. Benzer şekilde, çoklu doğrusal regresyon sonucu, hanehalkı reislerinin yaşı, tropik hayvancılık tutumu, iyileştirilmiş kahve tohumuna erişim, krediye erişim ve toplam arazi sahibi olma durumunun, kahve üreticilerinin toplam yıllık gelirini istatistiksel olarak etlilediği görülmüştür. Dolayısıyla kahve üreticilerinin toplam gelirlerinin arttırılmasında bu değişkenlerin dikkate alınması gerekmektedir.

\section{INTRODUCTION}

Coffee is considered as the most important traded commodity in the world economy and is the leading item in generating foreign exchange for Ethiopia as it contributes more than 25 percent of the country's foreign exchange earnings (ECEA, 2013). Ethiopia is the birth place of Arabica coffee and currently, the leading producer in Africa and fifth worldwide. Majority of the Ethiopian population derives its livelihood from this cash crop. In Ethiopia, coffee is largely produced in central part of the country (Oromiya region) and south part (South Nations, Nationalities, and Peoples' region). Around90 
percent of this production is based on the smallholder farmers. The estimated total production of Ethiopian coffee per annum is around 400,000 tons with the annual total export of 200,000 tons which valued at 500 million (US dollar). Three countries namely, Brazil, Vietnam and Columbia produce more than 50 percent of the world's production. Ethiopia and Brazil are of the few countries that consume significant amount of their own production (ITC, 2011).

Specific governmental policies are not developed for production of coffee in Ethiopia and the production systems are varied across the regions. Production of coffee through different extension services such as seedlings and research based productions are supported by the government. Now days, the total land area allotted to coffee production is increasing due to increasing new planting. The four unique production systems in the country are forest coffee, semi-forest coffee, garden coffee and plantation coffee. Each of these unique production systems has their own characteristics as well as contributions in economic growth of the country. Forest coffee is a wild coffee grown under the shade of natural forest trees and Semiforest coffee is more intensive with increased farming interventions. Semi-forest coffee needs adequate shade in addition to sunlight which is obtained by thinning of forest trees. Garden coffee is planted by farmers nearby their residence while plantation coffee is planted by the government or by private investors for the purpose of export (Abu and Teddy, 2013). Ethiopia accounts for about 4.5 percent of global coffee production and the estimated 15 million people sustain their livelihood from this sector (Abu, 2016).

The export process of Ethiopian coffee is done through three consecutive channels namely local trade, Ethiopian commodity exchange (ECX) and international trade. Farmers sell their coffee to traders and cooperatives at local level while traders and cooperatives pass it to ECX. Direct sale to foreign traders bypass ECX and is only available to cooperative union and large commercial operations (Abu, 2015). Modern coffee marketing is based on coffee standard classification, grading and licensing. Ethiopia established National Coffee Board in 1957with specific objectives of regulating coffee marketing in the country and improving its quality for export. The board has its own operational rules, regulations and modalities for coffee inspection, grading and auction. Coffee marketing is constrained by high transaction cost, lack of adequate local standard processing and handling facilities, centralized coffee inspection and grading system, lack of export marketing skill and inconsistency in coffee quality (ECXA, 2008).

The general motive of the present study is that little is empirically known about the livelihood outcomes of the coffee producers in the study district. Even the studies conducted on coffee marketing in Ethiopia, for instance (Demeke, 2007; Tinsae, 2008 and Anteneh et al., 2011), are mostly focused on coffee cooperatives and marketing related constraints. In the study area, the main cash crop is coffee and the livelihoods of smallholder farmers highly rely on this crop. But, determinants of livelihood outcomes of coffee producing farmers have never been studied specifically in the study area. Therefore, it is necessary to undertake empirical study to fill the above mentioned information gap. The main contribution of this study is that it can be used as a best stepping-ground for other studies on livelihood analysis in the study site. With this brief introduction, the rest of the paper is structured as follows. The next section presents Literature review; the third section describes data and methodology; the fourth section describes key findings and implications and the fifth section presents conclusion and Recommendations.

\section{LITERATURE REVIEW}

\subsection{Basic concepts of livelihood outcomes}

Livelihood is a broad concept and deals with a wide range of opportunities and constraints. Livelihood (Kanji et al., 2005) includes capabilities, assets (both material and social resources), and all activities required for a means of living. Livelihood strategies (Ellis and Clark, 2007) are a combination of activities and choices made by people to achieve livelihood goals or outcomes which includes productive activities, investment strategies and reproductive choices. The primary method of understanding livelihood outcomes is to develop the general understanding of local definitions of poverty. Livelihood outcome (DFID, 2006) is achievements of livelihood strategies such as more income and increased well-being. In most cases, livelihood outcomes can be explained as the inverse of poverty. That is, if poverty is described as food insecurity, powerlessness and a lack of access to key services, then the required livelihood outcomes would be food security, a sense of power and dignity and improved access to services. The livelihood outcome (ERD, 2010) can be 
expressed as the goals to which people aspire the results of pursuing their livelihood strategies. These strategies include increased income, reduced vulnerability, increased wellbeing, improved food security, and more sustainable use of natural resources. Livelihood outcomes are very crucial to handle the results of the livelihoods strategies. In particular, it is used to explore opportunities and constraints faced by people in pursuing different livelihood options.

Education and income are among the primary indicators of livelihood outcomes since they are used as tools for eradication of poverty and improvement of livelihood options. Keeping the concept of poverty, education and income have direct relation in the progress of economic growth and sustainable development. Education (Hamman2006) is the general gain of values, knowledge, skills and attitudes. It is designed to remove the chains of ignorance, superstition and diseases, and it helps people to earn more income and become more productive. In assessing long term progress, the Human Development Index (HDR, 2013)is famous in using long and healthy life, access to knowledge and a decent standard of living as basic dimensions of human development. Access to knowledge is measured by mean years of schooling for the adults and the expected years of schooling for children of school entrance age. In other ways, household income and wealth are essential component of individual wellbeing. The ability to command resources allows people to satisfy basic needs and pursue many other goals for their lives. Economic resources enhance individuals' freedom to choose the lives that people want to live and protect them against economic and personal risk (Balestra and Sultan, 2013). Different sources of income of rural households are discussed by (Tasieet al., 2012). These sources include small scale agriculture and livestock production, selling of trees and fruit, engagement in non/off-farm activities and remittance.

\subsection{Related empirical studies}

There have been some empirical studies regarding livelihood analysis of rural households and different scholars use different indicators of livelihood outcomes. For instance Adem (2005) investigated socioeconomic impact of export oriented agriculture on the livelihood of farmers in eastern Ethiopia and found out different factors affecting schooling of children. According to his study, the area allotted to khat has positive and significant impact on the percentage of children sent to school in eastern Ethiopia whereas the number of cows owned by the farmer has negative impact on the percentage of children sent to the school with the possible reason that children help parents by looking after the cattle. Chaudrury et al., (2008) confirmed households with better educated adults and those living in better educated communities are more likely to have children enrollment in the school whereas the distance of the nearest school negatively affects the enrollment and completion probabilities in rural areas of Ethiopia. Another study by Adem et al. (2012) confirmed that 82\% of the households had at least one member dropped out of school, permanently in Arsi zone, Ethiopia and literacy rate decreases with the age of household head whereas increases with livestock asset size which is a proxy to wealth. According to Tullao and Rivera (2009), limiting family size and household income in addition to access to basic public service increase school participation both in urban and rural areas of eastern Samar.

Income diversification is another indicator of livelihood options for rural households and can be influenced by different socioeconomic and demographic factors. Amare and Belaineh (2013) found out determinants of income diversification among rural households in Fed is district, Ethiopia. According to this study, male headed households have obtained better self-employment income. The reason is that male headed households have the ability to access more profitable off-farm self-employment activities than the female headed households. Those household heads that have formal education are better in decision making ability to participate in to different profitable self-employment activities and get more income than illiterate households. According to Arega et al. (2013), rural households' annual income proxy to livelihood outcome is positively influenced by livestock ownership, access to credit, and engagement in non-farm/off-farm activities. Access to credit helps households to diversify their livelihood options by filling food gaps in drought-prone areas of Ethiopia. Livestock holding is highly significant in achieving livelihood strategies as it improves the level of household income. Improving livelihood outcomes of rural households requires interventions aimed at improved natural resources management and diversification of livelihood strategies. These interventions include creating sound non-farm/off-farm employment opportunities. Aikaili (2010) confirmed education of household head, farm size and ownership of non-farm rural enterprise as important factors determining rural households' income in Tanzania. According to Yishak (2016), 
farmers' participation in income diversification in rural Ethiopia is influenced by various variables such as sex and education level of household head, farm income, participation in local leadership and ownership of livestock.

Thus, this present study tries to explore the determinants of livelihood outcomes of coffee producers with particular emphasis on education of children and annual total income of coffee farmers in Lalo Assabi district which is one of the coffee producing districts in western Ethiopia. This study attempts to address the following questions. What are the characteristics of coffee producers regarding education of children and annual total income? What are the major determinants of livelihood outcomes of coffee producers as indicated by education of children and annual total income of the producers?

\section{DATA and METHODOLOGY}

\subsection{Description of the study area}

Lalo Assabi district is one of the 19 districts of West Wollega zone of Oromiya national regional state, Ethiopia. West Wollega zone is located in the western part of the country at a distance of 441 kilometers from Addis Ababa, the capital city of the country. The capital city of the district is called Inango and it is 23 kilometers away from zonal city, Gimbie. The district is situated at latitudinal and longitudinal ranges of 190to $200 \mathrm{~N}$ and 350 to $450 \mathrm{E}$ geographical grids, respectively. The climate condition of the district is confortable for both livestock and honey productions in addition to crop production (LAWARDO, 2015).

\subsection{Sampling procedure and Sample size}

Lalo Assabi district is selected for the study due to the fact that being coffee is the main source of livelihood for the district, the livelihood figures of these people have not been explored yet. In order to select a representative sample, a three-stage random sampling technique was implemented to select coffee producing households for interview. In the first stage, district is divided into Kebeles and the kebeles are considered as strata. In the second stage, since the number of stratum is large, all strata could not be included in the study. Therefore, following Chocran (1963), four kebeles which have large proportions of coffee producing households are selected. In the third stage, households were selected from the selected rural kebeles by systematic sampling based on probability proportional to size.

In calculating the required sample size, $\mathrm{P}$ is taken proxy to the proportion of households' income obtained from coffee production and/or marketing. The value of $\mathrm{p}$ is fixed at 0.5 since there is no previous study on the same title in the study area. Using the formula of sample size determination for stratified random sampling, the required sample size for this study is calculated as follows.

$\mathrm{n}=\frac{\sum\left(\frac{\mathrm{N}_{\mathrm{h}}^{2} \mathrm{~A}_{\mathrm{h}}}{\mathrm{W}_{\mathrm{h}}}\right)}{\mathrm{N}^{2} \mathrm{D}^{2}+\sum \mathrm{N}_{\mathrm{h}} \mathrm{A}_{\mathrm{h}}}$, Where $\mathrm{D}=\frac{\mathrm{C}}{\mathrm{Z}_{\frac{\alpha}{2}}}$ and $\mathrm{A}_{\mathrm{h}}=\mathrm{P}_{\mathrm{h}}\left(1-\mathrm{P}_{\mathrm{h}}\right)$,

C- is a margin of error which a researcher tolerates in the estimation.

$Z_{-}(\alpha / 2)$ - is the value of standard normal distribution for a given level of significance.

$\mathrm{N}$ - is population size (The sum of all households in the four selected kebele) and is total sample size required for the study.

W_h- is proportion of population of kebele to the population of the selected kebeles.

Using the above formula and settingC $=0.08, \alpha=0.05, \mathrm{~N}=1386$ and $\mathrm{P}=0.5$, the required sample size obtained is 141 . 


\subsection{Type of Data}

Primary data source was used to collect necessary information for the study and structured questionnaire was used to generate primary data from the selected households. The primary data was collected from January10, 2015 to February 16, 2015 using systematic random sampling based on the probability proportional to size. Statistical software package, SPSS version 20 is used for the analysis of data.

\subsection{Method of data analysis}

Multiple linear regressions were employed to identify factors affecting livelihood outcomes as measured by schooling of children proxy to wellbeing and annual total income of coffee producers. The model is selected for its practical applicability (Gujarati, 2007). Econometric model specification of the multiple linear regression models is:

$\mathrm{Y}_{\mathrm{i}}=\beta_{0}+\beta_{1} \mathrm{X}_{\mathrm{i} 1}+\beta_{2} \mathrm{X}_{\mathrm{i} 2}+\cdots+\beta_{\mathrm{k}} \mathrm{X}_{\mathrm{ik}}+\mathrm{U}_{\mathrm{i}}$,

Then we can write in matrix notation as:

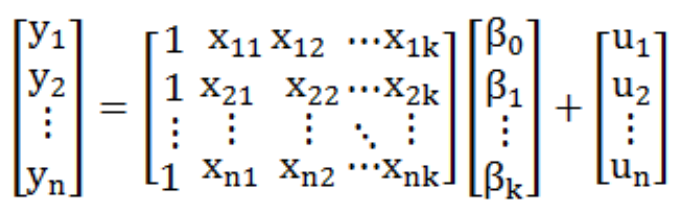

Or

$\mathrm{y}=\mathrm{X} \beta+\mathrm{U} 3.3$

$\mathrm{y}=\mathrm{an} \mathrm{n} \times 1$ Vector of observations on the explained variables (Mean years of education of school aged children and Annual total income, fitted independently). Mean year of education is calculated as the sum of years of education of school aged children $(>=7)$ divided by total number of school aged children in the family.

$\mathrm{X}=\mathrm{an} \mathrm{n} \times(\mathrm{k}+1)$ Matrix of observations on the explanatory variables (Socioeconomic and Demographic Variables)

The first column of 1 's represents the intercept term

$\mathrm{u}=\mathrm{an} \mathrm{n} \times 1$ Column vector of errors

$\beta=(k+1) \times 1$ Column vector of parameters to be estimated

Two separate regression models are fitted as follows.

Model 1:

$$
\begin{gathered}
y=\beta_{0}+\beta_{1} x_{1}+\beta_{2} x_{2}+\beta_{3} x_{3}+\beta_{4} x_{4}+\beta_{5} x_{5}+\beta_{6} x_{6}+\beta_{7} x_{7}+\beta_{8} x_{8}+\beta_{9} x_{9} \\
+u
\end{gathered}
$$

$y=$ Mean years of education of school aged children (year)

x_1 $=$ Sex of household head $(1=$ male, $0=$ female $)$

x_2= Age of household head (years)

$\mathrm{x} \_3=$ Education level of household head (years)

x_4= Household size (persons)

$\mathrm{x} \_5=$ Square root of annual total income (Birr)

x_6= Distance to elementary school (hour) 
x_7= Distance to high school (hour)

$\mathrm{x} \_8=$ Distance to preparatory school (hour)

x_9= School fee payment $(1=$ yes, $0=$ No $)$

Model 2:

$y=\beta_{0}+\beta_{1} x_{1}+\beta_{2} x_{2}+\beta_{3} x_{3}+\beta_{4} x_{4}+\beta_{5} x_{5}+\beta_{6} x_{6}+\beta_{7} x_{7}+\beta_{8} x_{8}+\beta_{9} x_{9}+\beta_{10} x_{10}$ $+u$

$\mathrm{y}=\log$ of annual total income (Birr)

$\mathrm{x} \_1=$ Sex of household head $(1=$ male, $0=$ female $)$

x_2= Age of household head (years)

$\mathrm{x} \_3=$ Education level of household head (years)

x_4= Household size (persons)

x_5= Livestock holding (TLU)

x_6 $=$ Access to improved coffee seed $(1=$ yes, $0=$ No $)$

x_7 $=$ Access to credit $(1=$ yes, $0=$ No $)$

x_8 $=$ Market distance (hour)

x_9= Total land owned (hectare)

x_10= Engagement in non-farm/off-farm activities $(1=$ yes, $0=$ No $)$

Method of Parameters Estimation: Given the model with the assumption, $\mathrm{u} \sim \mathrm{N}\left(0, \sigma^{\wedge} 2\right.$ I) and $\mathrm{n}$ set of observations on $\mathrm{y}$ and each explanatory variable, the estimation of model parameters follows the ordinary least square principle. The OLS estimators are obtained by minimizing sum square error as follows:

$\mathrm{Q}=\sum \widehat{\mathrm{u}}_{\mathrm{i}}^{2}=\sum\left(\mathrm{y}_{\mathrm{i}}-\widehat{\mathrm{y}}_{\mathrm{i}}\right)^{2}$, where $\sum \widehat{\mathrm{u}}_{\mathrm{i}}^{2}$ is residual sum of squares (RSS).

In matrix notation, this amounts to minimizing $u u^{\prime}$, since

$\widehat{\mathrm{u}} \widehat{\mathrm{u}}^{\prime}=\left[\widehat{\mathrm{u}}_{1} \widehat{\mathrm{u}}_{2} \cdots \widehat{\mathrm{u}}_{\mathrm{n}}\right]\left[\begin{array}{c}\widehat{\mathrm{u}}_{1} \\ \mathrm{\textrm {u }}_{2} \\ \vdots \\ \widehat{\mathrm{u}}_{\mathrm{n}}\end{array}\right]=\widehat{\mathrm{u}}_{1}^{2}+\widehat{\mathrm{u}}_{2}^{2}+\cdots \widehat{\mathrm{u}}_{\mathrm{n}}^{2}=\sum \widehat{\mathrm{u}}_{\mathrm{i}}^{2}$

Nowu $=\mathrm{y}-\mathrm{x} \beta \hat{}$, therefore

$\hat{\mathrm{u}}^{\prime} \mathrm{u}=(\mathrm{y}-\mathrm{x} \widehat{\beta})^{\prime}(\mathrm{y}-\mathrm{x} \widehat{\beta})=\mathrm{y}^{\prime} \mathrm{y}-\widehat{\beta}^{\prime} \mathrm{x}^{\prime} \mathrm{y}-\mathrm{y}^{\prime} \mathrm{x} \widehat{\beta}+\widehat{\beta}^{\prime} \mathrm{x}^{\prime} \mathrm{x} \widehat{\beta}=\mathrm{y}^{\prime} \mathrm{y}-2 \widehat{\beta}^{\prime} \mathrm{x}^{\prime} \mathrm{y}+\widehat{\beta}^{\prime} \mathrm{x}^{\prime} \mathrm{x} \hat{\beta}$

Since $\beta^{\wedge^{\prime}} x^{\wedge^{\prime}}$ yis scalar (a real number), it is equal to its transpose, $y^{\prime} x \beta^{\wedge}$. We find the OLS estimator of $\beta^{\wedge}$ of $\beta$ by taking partial derivative of Residual Sum Square $\left(\sum \hat{\mathrm{u}}_{\mathrm{i}}^{2}\right)$ with respect to $\beta^{\wedge}$ and solving them by equating to zero. That is,

$\frac{\partial \sum \widehat{\mathrm{u}}_{\mathrm{i}}^{2}}{\partial \widehat{\beta}^{\prime}}=\frac{\partial \hat{\mathrm{u}}^{\prime} \hat{\mathrm{u}}}{\partial \hat{\beta}^{\prime}}=\frac{\partial}{\partial \widehat{\beta}^{\prime}}\left(\mathrm{y}^{\prime} \mathrm{y}-2 \widehat{\beta}^{\prime} \mathrm{x}^{\prime} \mathrm{y}+\widehat{\beta}^{\prime} \mathrm{x}^{\prime} \mathrm{x} \hat{\beta}\right)=0-2 \mathrm{x}^{\prime} \mathrm{y}+2 \mathrm{x}^{\prime} \mathrm{x} \beta=0$ 
This implies that

$\mathrm{x}^{\wedge^{\prime}} \mathrm{x} \beta \hat{=} \mathrm{x}^{\wedge^{\prime}} \mathrm{y}($ Normal equation)

If the inverse of $\left(x^{\wedge^{\prime}} x\right)$ exists, say $\left[\left(x^{\wedge^{\prime}} x\right)\right]^{\wedge}(-1)$, then pre multiplying both sides of normal equation by this inverse and we obtain:

$\llbracket\left(\mathrm{x}^{\wedge^{\prime}} \mathrm{x}\right) \rrbracket^{\wedge}(-1) \mathrm{x}^{\wedge^{\prime}} \mathrm{x} \beta=\llbracket\left(\left(\mathrm{x}^{\wedge^{\prime}} \mathrm{x}\right) \rrbracket^{\wedge}(-1) \mathrm{x}^{\prime} \mathrm{y}\right.$

$$
\widehat{\boldsymbol{\beta}}=\left(\mathbf{x}^{\prime} \mathbf{x}\right)^{-1} \mathbf{x}^{\prime} \mathbf{y} 3.6
$$

The solution of the normal equation (3.6) is the estimate of $\beta$ that minimizes RSS. $y \hat{=}=x \beta$ is the fitted regression model.

Test of the overall significance of a regression: This test aims at finding out whether the explanatory variables $\left(\mathrm{X}_{-}(1)\right.$, $\left.\mathrm{X} \_2, \ldots, \mathrm{X} \_\mathrm{k}\right)$ do actually have any significance influence on the dependent variable. Formally the test of the overall significance of the regression implies testing the null hypothesis:

H_0: $\beta \_1=\beta \_2=\cdots \beta \_\mathrm{k}=0$ against the alternative hypothesis

H_1: Not all $\beta \_\mathrm{i}^{\wedge}{ }^{\wedge} \mathrm{s}$ are zero.

The test of the overall regression is carried out with the table of analysis of variance (ANOVA) and the test statistic is given by:

$$
\mathrm{F}^{*}=\frac{\mathrm{SS}_{\mathrm{R}} / \mathrm{k}}{\mathrm{SS}_{\mathrm{Res}} /(\mathrm{n}-\mathrm{k}-1)}
$$

Where, $S S_{R}$ is sum square regression and $S S_{\text {Res }}$ Res is sum square residual. The test statistic is compared with the tabulated $\mathrm{F}$ (at the chosen level of significance)

$\mathrm{v}_{1}=\mathrm{k}$ and $\mathrm{v}_{2}=\mathrm{n}-\mathrm{k}-1$ degrees of freedom and $k$ is number of explanatory variables.

Test of Multi collinearity: The presence of multi collinearity among the explanatory variables seriously affects the parameter estimates of any regression model. The Variance Inflation Factor (VIF) technique is employed to detect the problem of multi collinearity. VIF can be defined as;

$\operatorname{VIF}\left(\beta_{\mathrm{j}}\right)=\frac{1}{1-\mathrm{R}_{\mathrm{j}}^{2}}$

Where $\mathrm{R}_{\mathrm{j}}^{2}$ is the squared multiple correlation coefficient between $X_{j}$ and other explanatory variables. As a rule of thumb, if a VIF of a variable exceeds 10, the variable is said to be highly collinear (Gujarati, 2007).

\section{RESULTS and DISCUSSION}

\subsection{Descriptive Results}

\subsubsection{General characteristics of households}

Table 1 presents demographic and socioeconomic characteristics of the sampled respondents. The total sample size of respondents handled during the survey was 141 coffee producers. Out of the total sampled respondents, $122(86.5 \%)$ were 
male-headed and 19 (13.5\%) were female-headed households. The analysis of marital status shows that 3(2.1\%), 115 (81.6\%), 21 (14.9\%) and $2(1.4 \%)$ were single, married, widowed and divorced household heads, respectively. Regarding cooperative membership, $98(69.5 \%)$ of the sampled households are members of different agricultural cooperatives and 43 $(30.5 \%)$ are not organized under any agricultural cooperatives. Coffee production is the main occupation and source of livelihood for all sample farmers. That means all sampled households generate income from coffee marketing and/or production to run their day-to-day livelihood. The average age of the sampled respondents was 46.36 years with standard deviation of 14.61. The average year of education of sampled respondents was found to be 5.38 years with standard deviation of 3.82. The average household size per household was 6.26 persons with standard deviation of 2.55. The distance of the nearest market is also taken into account and the average distance of the nearest market from households' residence is found to be 0.73 hours with standard deviation of 0.40 .

Table 1. General characteristics of sampled households

\begin{tabular}{|c|c|c|c|c|c|c|}
\hline \multicolumn{4}{|c|}{ Categorical Variables } & \multicolumn{3}{|c|}{ Continuous Variables } \\
\hline & $\stackrel{\Xi}{\Xi}$ & 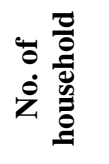 & 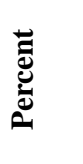 & 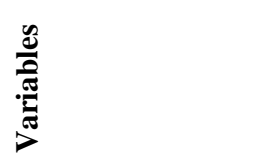 & $\sum_{\Sigma}^{\varpi ँ}$ & $\begin{array}{l}\vec{d} \\
\dot{\vec{d}} \\
\dot{\vec{\infty}}\end{array}$ \\
\hline \multirow[t]{2}{*}{ Sex } & Male & 122 & 86.5 & Age (years) & 46.36 & 14.61 \\
\hline & Female & 19 & 13.5 & education (year) & 5.38 & 3.82 \\
\hline \multirow[t]{4}{*}{ Marital status } & Single & 3 & 2.1 & $\begin{array}{l}\text { Household size } \\
\text { (number) }\end{array}$ & 6.26 & 2.55 \\
\hline & Married & 115 & 81.6 & $\begin{array}{l}\text { Distance to the } \\
\text { market (hour) }\end{array}$ & 0.73 & 0.40 \\
\hline & Widowed & 21 & 14.9 & & & \\
\hline & Divorced & 2 & 1.4 & & & \\
\hline Cooperative & Yes & 98 & 69.5 & & & \\
\hline Membership & & & & & & \\
\hline
\end{tabular}

Source: Computed from survey, 2015

\subsubsection{Schooling Condition}

Education is one of the livelihood outcomes which generates sustainable economic growth and plays indispensable role in poverty reduction and improving wellbeing. Any developing country aiming to have strong global economic, political and social competitiveness should maintain both increased enrollment and high quality expansion in its educational system. Table 2 depicts that the literacy rate in the study area was 78.45 described as percentage. The result of the study demonstrates that more than three fourth of school aged children were at school or ever reached a school and this shows that schooling status is on a good status in the study area. The average mean year of education of school aged children in the family was found to be 6.02 years with standard deviation of 2.50 .

Table 2. Literacy rate and mean year of education

\begin{tabular}{lcc}
\hline Variable & Mean & St. dev \\
\hline Literacy rate & 78.45 & 36.37 \\
Mean year of education & 6.02 & 2.50 \\
\hline
\end{tabular}

Source: Computed from survey, 2015 


\subsubsection{Income distribution of sampled households}

Agricultural activities such as crop and livestock productions are the dominant source of income for small scale farmers in Lalo Assabi district. Table 3 depicts the income distribution of sampled households. The analysis of the household income depicts that the average annual income of households was 8719.65 Birr with standard deviation of 5635.47. The average income of sampled households from coffee in a given coffee year prior to survey year was 6119.57 Birr with standard deviation of 4102.74 and this is around $70 \%$ of their annual total income. This result supports the fact that the major source of annual income in the study area is obtained from coffee production and/or marketing. The survey result depicts that there is extremely large variation regarding the annual total income of the selected households. Even though the farmers are well experienced in coffee production, the output and the income they earn from this sector is not proportional with their experience. That means they have high experience of production but they get low output and income from this sector. The probable reason is that majority of them do not use improved coffee seed for production of coffee. They prepare improved coffee seed by themselves which is not pretested before use and this may lower the output.

Table 3. Income distribution of sampled households

\begin{tabular}{lcc}
\hline Variable & Mean & St. dev \\
\hline $\begin{array}{l}\text { Annual total income prior to } \\
\text { survey year (Birr) }\end{array}$ & 8719.65 & 5635.47 \\
Income from coffee (Birr) & 6119.57 & 4102.74 \\
\hline
\end{tabular}

Source: Computed from survey, 2015

\subsection{Determinants of Livelihood Outcomes}

\subsubsection{Determinants of Schooling of Children}

The analysis of variance shows that the overall regression model is significant $(\mathrm{F}=6.509)$ and $70.9 \%$ of the mean year of education of school aged children is explained by the explanatory variables under consideration. The existence of multi collinearity problem is checked for all explanatory variales. Following this, the variable "number of dependent" was omitted from the analysis due to multi collinearity problem. The values of VIF for the rest of explanatory variables are less than 10 and range from 1.133 to 1.881 (Table 4).

Table 4. VIF test of explanatory variables of schooling condition

\begin{tabular}{l|cc}
\hline \multirow{2}{*}{ Explanatory Variables } & \multicolumn{2}{c}{ Collinearity Statistics } \\
\cline { 2 - 3 } & Tolerance & VIF \\
AGE & 0.847 & 1.181 \\
EDUC & 0.532 & 1.881 \\
FAMSIZE & 0.662 & 1.510 \\
SQRTATTINC & 0.705 & 1.419 \\
DISTPES & 0.879 & 1.137 \\
DISTHIGHS & 0.735 & 1.361 \\
DISTPREP & 0.823 & 1.215 \\
SCHFPAY & 0.883 & 1.133 \\
\hline
\end{tabular}

Source: Computed from survey, 2015

The estimates of the parameters of the variables expected to determine factors affecting schooling of children proxy to wellbeing are displayed in Table 5. Among a total of nine explanatory variables included in the regression model, five explanatory variables were found to have significant relationship with mean year of education of school aged children. These are sex, age and year of education of household head, square root of annual total income of parents and distance to preparatory school. Square root transformation is applied on annual total income to minimize variability. The model is fitted and significant variables are discussed as follows:

Model 1:

$\mathrm{y}^{\wedge}=0.029-1.079 \mathrm{x} \_1+0.055 \mathrm{x} \_2+0.330 \mathrm{x} \_3+0.013 \mathrm{x} \_4-0.332 \mathrm{x} \_5$ 
$\mathrm{Y}=$ Mean year of education of school aged children

$\mathrm{X} 1=$ Sex of household head (SEX)

$\mathrm{X} 2$ = Age of household (AGE)

$\mathrm{X} 3$ = Year of education $\mathrm{f}$ household head (EDUC)

$\mathrm{X} 4=$ Square root of annual total income (SQRTINCOME)

X5 = Distance to preparatory school (DSTPREP)

Sex of the household head (SEX): Sex of household head had negative and significant relationship with schooling of children. The negative sign implies that if the household head is male, the mean year of education of school aged children is expected to decrease by 1.079 yearholdingother variables constant. This finding is contradictory with the general belief that female headed households are not more likely to experience school participation of their children. This could be attributed due to the fact that school education is largely free in the study area.

Age of household head (AGE): Age of household head had positive and significant relationship with schooling of children and the result suggests that for one year increase in the age of household head, there is expected increase of 0.055 years in the mean year of education of school aged children holding other variables constant. The implication of the result is that aged parents often appreciate the importance of education and influence their children to stay at school. But, as children grow, they begin to take on their own decision and the influence of parents tends to be reduced. This result is contradictory with the result obtained by Adem et al. (2012) who noted the negative relationship between age of household head and literacy rate.

Year of education of household head (EDUC): Year of education of household head is highly significant and had positive relationship with schooling of children. The result shows that for one year increase in year of education of household head, there is expected increase of 0.330years in the mean year of education of school aged children holding other variables constant. The result obtained is in line with the result obtained by Chaudhury et al. (2008) who noted that households with better educated adults and those living in better educated communities are more likely to have children enrolled in school.

Square root of annual income of parents (SQRTATTI): Annual total income was transformed using square root transformation to minimize the variance. The result confirmed that the magnitude of square root of households' annual total income positively and significantly related with schooling of children. Economically active households are more likely to send their children to the school than economically inactive households. The result conveyed that for each unit increase in square root of annual total income of parents, there is expected increase of 0.013 years in the mean year of education of school aged children holding other variables constant.

Table 5. OLS estimation of coefficients of MLR of determinants of schooling of children

\begin{tabular}{lcccc}
\hline Model & B & S. E & T & P-value \\
\hline (Constant) & 0.029 & 1.118 & 0.026 & 0.979 \\
SEX (1=Male) & -1.079 & 0.575 & -1.878 & $0.063^{* *}$ \\
AGE & 0.055 & 0.017 & 3.212 & $0.002^{*}$ \\
EDUC & 0.330 & 0.058 & 5.671 & $0.000^{*}$ \\
HHSIZE & 0.034 & 0.085 & 0.408 & 0.684 \\
SQRTINCOME & 0.013 & 0.007 & 1.837 & $0.069^{* *}$ \\
DISTPES & 0.446 & 0.878 & 0.507 & 0.613 \\
DISTHIGHS & 0.228 & 0.699 & 0.326 & 0.745 \\
DISTPREP & -0.332 & 0.197 & -1.683 & $0.095^{* *}$ \\
SCHFPAY (1=yes) & 1.353 & 1.168 & 1.158 & 0.249 \\
\hline Dependent Variable: Mean year of education of school aged children & \\
N=141 R ${ }^{2}=70.9 \%$ & F=6.509 & Significance level: $1 \%(*)$ and $10 \%(* *)$ & \\
\hline
\end{tabular}


Distance to preparatory school (DISTPREP): Distance to preparatory school had negative and significant relationship with schooling of children. The negative sign implies that for one hour increase in distance to preparatory school, the mean year of education of school aged children is expected to decrease by 0.332 year holding other variables constant. The result obtained is in line with the result obtained by Chaudhuryet al. (2008) who noted negative relationship between distance to the school and school enrollment.

\subsubsection{Determinants of annual total income}

The analysis of variance showed that the overall regression model is significant $(\mathrm{F}=10.097)$ and $63.6 \%$ of the $\log$ of annual total income of coffee producing farmers is explained by the explanatory variables under consideration. The result of VIF values for the explanatory variables are less than 10 and range from 1.033 to 2.077 . This shows that there is no problem of multi collineraity. See Table 6.

Table 6. VIF test of explanatory variables of Log of annual total income

\begin{tabular}{l|cc}
\hline \multirow{2}{*}{ Explanatory Variables } & \multicolumn{2}{|c}{ Collinearity Statistics } \\
\cline { 2 - 3 } & Tolerance & VIF \\
\hline SEX & 0.860 & 1.163 \\
AGE & 0.481 & 2.077 \\
EDUC & 0.647 & 1.545 \\
FAMSIZE & 0.663 & 1.508 \\
TLU & 0.785 & 1.273 \\
AIMPSEED & 0.877 & 1.140 \\
ACRDT & 0.968 & 1.033 \\
MKTDIS & 0.876 & 1.141 \\
TLSIZE & 0.743 & 1.346 \\
ENNA & 0.852 & 1.174 \\
\hline
\end{tabular}

Source: Computed from survey, 2015

The estimates of the parameters of the variables expected to influence annual total income of selected households were displayed in Table 7. From the survey result, the variance of annual total income is found to be high and logarithmic transformation was applied to reduce the variance. Among total of ten explanatory variables included in the multiple linear regression model, five explanatory variables are found to have significant influence on the log of annual total income. These are age of household head, tropical livestock unit, access to improved coffee seed, access to credit and total land owned by households. The model is fitted and significant variables are discussed as follows:

Model 2:

$\mathrm{y}=3.692+0.003 \mathrm{x} \_1+0.025 \mathrm{x} \_2-0.288 \mathrm{x} \_3+0.117 \mathrm{x} \_4+0.152 \mathrm{x} \_5$

$\mathrm{Y}=\mathrm{Log}$ of annual total income

$\mathrm{X} 1=$ Age of household $(\mathrm{AGE})$

$\mathrm{X} 2$ = Tropical livestock unit (TLU)

$\mathrm{X} 3$ = Access to improved coffee seed (AIMPSEED)

$\mathrm{X} 4=$ Access to credit (ACRED)

$\mathrm{X} 5$ = Total land size $(\mathrm{TLAND})$

Age of household head (AGE): Age of household head is found to have positive and significant relationship with log of annual total income. The result suggests that for one year increase in the age of household head, there is expected increase 
of 0.003 in the log of annual total income of the coffee producers holding other variables constant. The implication of this result is that aged households are wise in resource use and in search high income for the future need. That is, as age of household increases the awareness of capital accumulation will be increased in a sense that he or she can use the accumulated capital at the time he or she becomes dependent (non-working age). The result obtained is contradictory with the result obtained by Amare and Belaineh (2013) who found the negative relationship between age of household head and self-employment income.

Tropical Livestock Unit (TLU): The result depicts that there was positive and significant relationship between tropical livestock unit and log of annual total income. The parameter estimate of TLU suggests that for one unit increase in the tropical livestock holding, there is expected increase of 0.025 in the log of annual income of the coffee producers keeping other variables constant. Households owning large livestock have the capacity to build up capital and handle cash constraints for participation in coffee production and/or marketing as compared to those with small or no livestock holding. The result obtained is in line with the result obtained by Arega et al. (2013) who found that ownership of livestock is strongly and positively related to total annual income of households.

Access to improved coffee seed (AIMPSEED): Improved seed is also one of the most important inputs that promote production and productivity of coffee. Improved coffee seed would increase the quality and quantity of output thereby increases the annual total income. But, the result of the current study reveals that improved coffee seed had negative and significant relationship with the log of annual total income. This condition may occur where the farmers do not use improved seed properly. In the study area, majority of the farmers prepare coffee seed by themselves which is not pretested. The other probable reason is that improved coffee seed is used by small proportion of farmers. The result is contradictory with LIPTON (2005) who found that access to improved seed can increase agricultural productivity by boosting overall production thereby increases annual total income.

Access to credit (ACRED): Access to credit is found to have positive and significant relationship with log of annual total income. The result depicts that if a household has access to credit, his/her log of annual total income is expected to increase by 0.117 holding other variables constant. The implication is that access to credit would enhance the financial capacity of the farmers to purchase the agricultural inputs, thereby increasing the coffee production and market share size. The result obtained is in line with the result obtained by Arega et al. (2013) who noted that access to credit has positive and significant correlation with annual total income.

Total land owned (TLAND): The result shows that total land and log of annual income had positive and significant relationship. The result depicts that for one hectare increase in total land owned by a household, there is expected increase of 0.152 in log of annual total income of coffee producers holding other variables constant. Increasing land owned is more effective to earn more income if complemented by improvements in inputs such as the mechanization of agriculture and use improved seed. A household owning large size of land has the possibility to produce more income generating productions than a household owning small size of land. The result is in line with the result obtained byAikaeli (2010) who identified increasing acreage of farm land is more effective to earn more income.

Table 7. OLS estimation of coefficients of MLR of determinants of annual total income

\begin{tabular}{lcccc}
\hline Model & B & S.E & T & P-value \\
\hline (Constant) & 3.692 & 0.098 & 37.515 & 0.000 \\
SEX (1=Male) & 0.005 & 0.054 & 0.088 & 0.930 \\
AGE & 0.003 & 0.002 & 1.893 & $0.065^{* *}$ \\
EDUC & 0.008 & 0.006 & 1.493 & 0.138 \\
HHSIZE & -0.004 & 0.008 & -0.478 & 0.633 \\
TLU & 0.025 & 0.007 & 3.449 & $0.001^{*}$ \\
AIMPSEED (1=Yes) & -0.288 & 0.054 & -5.283 & $0.000^{*}$ \\
ACRDT (1=Yes) & 0.117 & 0.035 & 3.386 & $0.001^{*}$ \\
MKTDIS & -0.036 & 0.046 & -0.770 & 0.443 \\
TLAND & 0.152 & 0.034 & 4.479 & $0.000^{*}$ \\
ENNA (1=Yes) & -0.047 & 0.041 & -1.147 & 0.254 \\
\hline
\end{tabular}




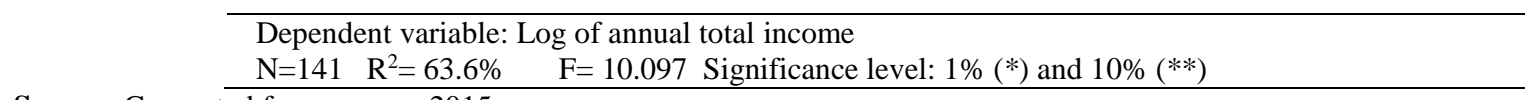

Source: Computed from survey, 2015

\section{CONCLUSION and RECOMMENDATIONS}

Majority of the annual total income of the farmers is generated from coffee production and/or marketing and the farmers have high coffee production experience in the study area. The study tried to access the livelihood outcomes of the coffee producers by giving special attention to the schooling of children proxy to wellbeing and annual total income of households. Schooling of children increases with the increase in the age of household head, year of education of household head and total annual income of parents and decreases with increase in distance to preparatory school. Matured households with better level of education and better economic status are more likely to send their children to the school at the right school age than young households with low level of education and less economic status. Annual total income is vital to improve the livelihood outcomes of the households. Thelog of annual total income increases with the increase in the age of household head, livestock holding (TLU), access to credit and total land owned by farm households where as decreases with access to improved seed due to improper use. Matured households with large ownership of livestock and those having large size of farm land are more beneficiary in generating income than those with small ownership of livestock and those with small farm land.

Some recommendations are forwarded based on the finding of the study. 1) The concerned authority should be able to increase the awareness of households about the school age at which their children should join the school. (2) Government intervention should be needed for the expansion of schools in which the communities would be equally benefited. (3) Households should seek other means of generating income in addition to coffee production to increase their annual total income in which they can improve their livelihood outcomes. (4) Awareness creation should be scheduled by development agents to the farmers about the benefits and use of the improved coffee seed.

\section{ACKNOWLEDGEMENT}

My special thanks and heartfelt gratitude extend to my wife Tigist Gizaw for her devotion in all aspects.

\section{REFERENCES}

ABU, T. (2015). “Coffee annual report”, Global Agricultural Information Network, Gain report number ET1514, Ethiopia.

ABU, T. (2016). “Coffee annual report”, Global Agricultural Information Network, Gain report number ET1615, Ethiopia.

ABU, T. AND TEDDY T. (2013). "Coffee annual report”, Global Agricultural Information Network, Gain report number ET1302, Addis Ababa, Ethiopia.

ADEM, K. (2005). "Socioeconomic impact of export oriented agricultural production on farmers in Eastern Ethiopia". Retrieved on December 12, 2014.

ADEM, K., BEZABIH E., WASSIE B. AND JEMMA H. (2012). "Education poverty among the rural households in Arsi zone, Oromiya, Ethiopia". School dropout and Literacy rate in focus. Universal Journal of Education and General Studies, ISSN-0984, 1(9): 7-8, available online at http://www.universalresearchjournals.org/ujegs. Accessed on April 27, 2014.

Aikaeli, J. (2010),” Determinants of rural income in Tanzania”. Research on poverty alleviation. An empirical approach, Research report 10/4.

AMARE, D. AND BELAIEH, L. (2013). "Determinants of income diversification among rural households": The case of smallholder farmers in Fedis district, Eastern hararghe zone, Ethiopia. Journal of Development and Agricultural Economics, 5(3): Available online at http://www.academicjournals.org/JDAE. Accessed on October 22, 2014. 
ANTENEH, A., MURADIAN, R. and RUBEN, R. (2011)."Factors affecting coffee farmers market outlet choice in Ethiopia”. Centre for International Development Issues Nijmegen, Radboud University, the Netherlands.

AREGA, B., WOLDEAMLAK, B. and NICOLAU, M. (2013). "Rural households' livelihood assets, strategies and outcomes in drought-prone areas of the Amhara Region, Ethiopia": Case study in Lay Gaint District. African Journal of Agricultural Research, 8(46): Available online at http://www.academicjournals.org/AJAR.Accessed on October 22, 2014.

BALESTRA, C. and SULTAN, J. (2013). "The determinants of residential satisfaction and its relation with well-being". OECD Statistics working papers, 2013/05, available online at http://dx.doi.org/10.1787/5jzbcx0czc0xen.Accessed on September 23, 2015.

CHAUDHURY, N., ASADULLAH M. and CHRITIAENSEH L. (2008). "Schools, households, risk and gender: Determinants of Child Schooling in Ethiopia", The World Bank.

CHOCRAN W. G. (1963), "Sampling Techniques”, Third edition, Harvard University, P-89.

DEMEKE, T. (2007). "Performance of coffee marketing cooperatives and members' satisfaction in Dale district", Southern Ethiopia.M.Sc Thesis, Haramaya University, Haramaya, Ethiopia.

DFID (Department for International Development). (2006). "Sustainable rural livelihoods guidance sheet”, UK, London.

ECEA [Ethiopian Commodity Exchange Authority]. (2013). "Coffee export marketing in Ethiopia", Addis Ababa, Ethiopia.

ECXA [Ethiopian Commodity Exchange Authority]. (2008). "Analysis of coffee supply, production, utilization and marketing issues and challenges in Ethiopia", Addis Ababa, Ethiopia.

Ellis, F. and Freeman, H. A. (2007). "Rural livelihoods and poverty reduction strategies in four African countries". Journal of Development Studies, 40 (4).

ERD (European Report on Agriculture) (2010). "Livelihoods strategies and household resilience to food insecurity". An empirical analysis to Kenya, Nairobi, Kenya.

GUJARATI, D.N, SANGEETHA. (2007). "Basic Econometrics", 4th edition, Tata McGraw-Hill, New Delhi.

HAMMAN, A.U. (2006). "The distribution of better life programs and beneficiaries in Maiduguri and Bama local government areas", University of Maiduguri.

HDR (Human Development Report). (2013). "The rise of the south": Human progress in a diverse world. Ethiopia.

ITC [International Trade Center]. (2011). "Ethiopian Coffee Quality Improvement Project”, Addis Ababa, Ethiopia.

Kanji, N., Mac Gregor, J. and Tacoli, C. (2005). "Understanding market-based livelihoods in a globalizing world": combining approaches and methods. International Institute for Environment and Development.

LAWARDO, (Lalo Assabi Woreda Agriculture and Rural Development Office)

.2015. "Report on the district profile", Inango, Ethiopia.

LIPTON, M. (2005). "The Family Farm in a globalizing world": The role of crop science in alleviating poverty. Washington D.C, USA.

TASIE, C.M., OFFOR, U.S. and WILCOX, G.I. (2012). "Determinants of off-farm income diversification in rivers state", Nigeria.

TINSAE, D. (2008).“Marketing performance of primary coffee Cooperatives in Wonago and Yirgacheffeworeda”, SNNP, M.Sc. Thesis, Haramaya University, Haramaya, Ethiopia. 
Tullao and Rivera. 2009. Economic, demographic, and other factors affecting school Participation among children in urban and rural households: The Case of Pasay and Eastern Samar. II (6).

YISHAK, G. (2016). "Rural households' income diversification": The case of Wolaita zone, southern Ethiopia. International journal of development and research, Vol. 2, no 12 . Available online at http://www.sciencepublshinggroup.com/j/ij 